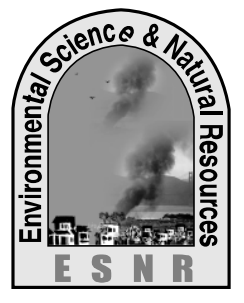

J. Environ. Sci. \& Natural Resources, 6(1): 209 - 216, 2013

ISSN 1999-7361

\title{
Use of Waste Energy by Adding Shing (Heteropneustes fossilis, Bloch 1797) into Pangus (Pangasianodon hypophthalmus, Sauvage, 1878) Pond
}

\author{
A. Ali, T. Akter ${ }^{1}$ and M. Das ${ }^{2}$ \\ Bangladesh Fisheries Research Institute \\ ${ }^{1}$ Department of Fisheries Management, Bangabandhu Sheikh Mujibur Rahman Agricultural University, \\ Gazipur, Bangladesh, \\ ${ }^{2}$ Department of Aquaculture, Bangladesh Agricultural University, Mymensingh
}

\begin{abstract}
An experiment was conducted to evaluate the growth, survival and production performances of pangus (Pangasianodon hypophthalmus) and shing (Heteropneustes fossilis) in which shing was used as guest to utilize the waste energy in pangus pond. The experiment was run for four months from July to October, 2008. Fishes were reared in pond no I, II, III with stocking den sity 150, 250 and 300 per decimal of pangus respectively. Shing was stocked only 10/decimal in pond-I. A complete artificial feed was used containing $23 \%$ protein. The weight gain $(385.17 \pm 2.15 \mathrm{~g})$ of pangus was significantly higher in pond-I than that of pond-II $(325.15 \pm 2.70 \mathrm{~g})$ and pond-III $(319.30 \pm 2.90 \mathrm{~g})$. However, the production of pangus per ha were $(28158.00 \pm 0.10 \mathrm{~kg})$ in pond-I, $(34159.112 \pm 0.50 \mathrm{~kg})$ in pond-II and $(37856.208 \pm 0.60 \mathrm{~kg})$ in pond-III. Total production of shing in pond-I was $240.57 \pm 1.60$ $\mathrm{kg} / \mathrm{ha} / \mathrm{yr}$. The survival rates $(\%)$ of pangus under three stocking densities were $98.66 \%, 85.06 \%$ and $80.00 \%$ respectively. The food conversion ratio (FCR) of pangasius pond I, II and III were 1.53, 1.81 and 1.84 respectively. The lowest FCR of 1.53 was found in pond-I. The net return of the pond I, II and III were BDT 273503.10, 117456.73 and 107906.60 per ha per year. The addition of shing into pangasius pond as guest invites economic benefit to the pangus culture.
\end{abstract}

Key words: Growth, Production, Stocking density, Survival rate, Tilapia

\section{Introduction}

Fish is an ideal source of protein and cheaper than any other food protein. Through the whole world it plays an important role in nutrition. The people of Bangladesh depend on fish as the principal source of animal protein. It fulfils $63 \%$ of animal protein requirement (DoF, 2005) of Bangladeshi people. In the total aquaculture production catfish particularly pangas is an important fish species and it receives popularity showing an importance substantially in terms of commercial culture. Currently the estimated pangas production in Bangladesh is 300,000 t/y producing from an area of 30,000 ha pond (Wahab et al., 2008). It indicates that pangasius has made a significant contribution for increasing fish production, poverty alleviation and livelihoods support in Bangladesh.

Thai pangus gained much popularity in Bangladesh because of its rapid growth, easy culture technique, high disease resistant and tolerance to a wide range of environmental adaptation (Bardach et al., 1972). Within 4 to 5 months it is possible to produce more than $500 \mathrm{~g}$ of individual catfish having marketing demand (Hossain, 2001). P. hypophthalmus is well accepted by a wide range of people and therefore, it has been a good source of protein and calorie for poor, middle class and also better- off people in rural as well as urban areas. People of this country economically benefited from pangus culture. It has gained a momentum in Bogra, Jessore, Noakhali, Dhaka and mainly in Mymensingh district for high growth, high demand and high market price. Over the years, pangasius production has been increasing day by day for grow out fish production.

The stinging catfish (Heteropneustes fossilis) is commercially as well as aquaculturally an important species in many Asian countries (Akand et al., 1991) and it is an indigenous species to Indo-PakBangladesh subcontinent. Stinging catfish is native to Bangladesh, Pakistan, and India including the Andaman Islands, Nepal, Srilanka, Burma, Thailand, Indus Basin and Laos (Talwar and Jhingran, 1992). $H$. fossilis is one of the cultivable species in Southeast Asia. It occurs in all types of inland water bodies and can survive for a longtime when keep in captivity even in a small quantity of water as it has a massive pair of sac-like pharyngeal lungs as accessory respiratory organ (Das, 1972). During dry season and winter months, the shing $(H$. fossilis) buries itself in the soil and aestivates in pits. Generally, many fishes live together in such pits.

In pangus culture system huge amount of artificial feed is used. A considerable amount of feed sediments as a waste feed into the bottom. These excess feed deteriorate water quality of the ponds. To use those leftover feed and grown benthos can save nutrition to a bottom dwelling fish and can add some portrayed in production. With the view bottom dwelling fish like shing (H. fossilis) could be stocked with pangus so that they consume the waste feed and also consume bottom living organisms that utilize waste feed in ponds. The combination of pangus and shing may enhance the utilization of waste energy into useable energy in the form of delicious muscle. 
The polyculture of pangus with other fish to use the leftover feed has been tried by a few researchers but there is no such result has been published.

In view of above facts an experiment was undertaken for the culture of pangus with shing to achieve the following objectives:

1. To evaluate the growth and production of pangus

2. To evaluate the growth and production of shing by using waste energy in pangus ponds and

3. To evaluate the profitability of the culture system.

\section{Materials and Methods}

\section{Experimental site}

The experiment was carried out for a period of four months from July to October, 2008 to evaluate the effect of added shing into pangus ponds for the utilization of waste energy. The study site is situated at Baragram under Upazilla Muktagaccha, Mymensingh. The experiment was conducted in three ponds having area of 10 to15 decimal.

\section{Pond preparation}

At first, water was drained from ponds. All aquatic vegetation in the littoral zone of the experimental ponds was removed by sharp scythe. Lime was applied at the rate of $100 \mathrm{~kg} / \mathrm{acre}$. Before applying lime, it was mixed with water carefully and kept exposed for overnight to avoid heat generation and then spread over the surface of the mud in a soluble form.

\section{Source of experimental fry}

The experimental pangus fry belonging to the same age group having average weight $31 \mathrm{~g}$ was brought from the Sharnalata Agrofarm, Radahkanai, Fulbaria, Mymensingh. Shing fry also collected from the same area almost similar size and age group.

\section{Design of experiment}

The experiment was conducted in three ponds at Baragram, Muktagaccha, Mymensingh. As the availability of the pond to be cultured in farmer's pond was limited, therefore the study was conducted without replication. The fry of pangus were released at three stocking densities of 150, 250 and 300 individuals/decimal which were designated as pond-I, pond-II and pond-III respectively. In pond-I, shing was stocked at the stocking density of 10/decimal. Fry were acclimatized with experimental pond water in plastic bag and then stocked at $10 \mathrm{am}$. In the past the scientific name of thai pangas was $P$. sutchi, P. hypophthalmus. Now the scientific name of thai pangas Pangasianodon hypophthalmus.

\section{Collection of artificial feed}

The artificial feed (Aftab Bohumukhi Farm Ltd.) was collected from local market, and the nutrients contents of feed were presented in Table-1

Table1: Nutrient Composition of feed

\begin{tabular}{|c|c|}
\hline Nutrient Components & Percentage(\%) of Nutrient \\
\hline Protein & 23 \\
\hline Fat & 6 \\
\hline Fibre & 8 \\
\hline
\end{tabular}

The cost of feed was BDT 21.00 per kg.

\section{Feeding method}

The feed was supplied $10 \%$ of fish body weight at the beginning of the experiment. Then it was adjusted to $8 \%$ after $2^{\text {nd }}$ sampling date and gradually it was readjusted to $7 \%$ and $6 \%$ of their body weight, after the $4^{\text {th }}$ and $6^{\text {th }}$ sampling date respectively. Half of the ration was supplied at 9.00 am and remaining half was supplied at $4.00 \mathrm{pm}$. The feeding was done direct broadcasting without any feeding trays.

\section{Water quality parameter}

The water quality parameters such as temperature, dissolved oxygen and $\mathrm{pH}$ were recorded on each sampling dates, in the morning at 9.00 am to 10.00 $\mathrm{am}$. The temperature and dissolved oxygen of the water was determined by DO meter (YSI Model-58, USA) and $\mathrm{pH}$ and recorded by $\mathrm{pH}$ meter (Model-445, UK).

\section{Sampling procedure}

Sampling was done by catching of ten fish from each pond with the help of a dharmajal at 15 days interval. The total weight of fishes was recorded by using ordinary balance. The fish were released in the respective ponds after recording the weight.

\section{Growth parameters}

Every 15 days interval, growth (g) was measured. To evaluate the fish growth the following parameters were used: weight gain $(\mathrm{g})$, percent weight gain SGR $(\%)$, survival rate $(\%)$, production $(\mathrm{kg} / \mathrm{decimal} / 120$ days), total production ( $\mathrm{kg} / \mathrm{ha} / \mathrm{yr})$.

\section{Weight gain (g)}

In the experiment weight gain was calculated as: Weight gain $(\mathrm{g})=$ Mean final weight - Mean initial weight

\section{Percent weight gain}

This is a fairly straightforward measure of the overall increase in mean body weight over a time period. 
$\%$ Weight gain $=\frac{\text { Mean final fish wt. }- \text { Mean initial fish wt. }}{\text { Mean initial wt. }} \times 100 \%$

\section{Specific growth rate ( $\%$ per day)}

The specific growth rate in the instantaneous change in weight of fish calculated as the percentage increase in body weight per day over given time internal. Growth in terms of weight was calculated by subtracting the initial weight of fish (at the time of release) from final weight of the same. The specific growth rate was calculated from the following formula

$\operatorname{SGR}(\%$ day $)=\frac{\left(\log _{\mathrm{n}} \mathrm{W}_{2}-\log _{\mathrm{n}} \mathrm{W}_{1}\right)}{\mathrm{T}_{2}-\mathrm{T}_{1}} \times 100$

Where, $\mathrm{T}_{1}$ (day) $\mathrm{W}_{1}=$ the initial live body weight $(\mathrm{g})$ at time $\mathrm{T}_{2}$ (day) $\mathrm{W}_{2}=$ the final live body weight $(\mathrm{g})$ at time

\section{Food conversion ratio (FCR)}

The food conversion ratio of pangus expressed by the rate of food consumed to weight gain was determined for each of the three stocking rates.

$$
\text { Food conversion ratio }(\mathrm{FCR})=\frac{\text { Food fed }}{\text { Live weight gain }}
$$

\section{Survival rate}

At the end of the experiment most of the fishes were caught by net and the rest by drying the ponds. It was calculated as

$$
\text { Survival rate }(\%)=\frac{\text { No. harvested }}{\text { No. } \text { stocked }} \times 100
$$

\section{Production}

At the end of the experiment most of the fishes were caught by net and the rest by drying the ponds. The production was calculated as

Production $=$ No. harvest $\times$ Final average weight.

\section{Economic analysis}

A simple cost return analysis was done to estimate the net profit from different ponds. The cost of leasing ponds was not included in the total cost. An additional $9.01 \%$ on total cost included as operational cost according to ADCP, (1983).

\section{Results and Discussion}

The results of the present study regarding compositions of water quality parameters, survival, growth and production of fishes are presented below.

\section{Water quality parameters \\ Water temperature $\left({ }^{\circ} \mathrm{C}\right)$}

The water temperature of the ponds varied from $28.5^{\circ} \mathrm{C}$ to $31.5^{\circ} \mathrm{C}$ during the study period (Table 2). The maximum temperature $\left(31.5^{\circ} \mathrm{C}\right)$ was recorded in pond-I in 30 July, 2008. The minimum temperature $\left(28.5^{\circ} \mathrm{C}\right)$ was noted in pond-III in 30 October, 2008. The average water temperature recorded in the ponds I, II and III were $30.188 \pm 0.84,30.00 \pm 0.72$ and $30.113 \pm 0.85$, respectively (Table 3 ).

\section{Dissolved oxygen $(\mathrm{mg} / \mathrm{l})$}

The dissolved oxygen content of the selected ponds ranged from 4.30 to $5.9 \mathrm{mg} / \mathrm{l}$ during the experimental period (Table 2). The lowest value of dissolved oxygen content was found $4.30 \mathrm{mg} / \mathrm{l}$ in pond-III in 30 September, 2008. The highest value of dissolved oxygen content was found $5.9 \mathrm{mg} / \mathrm{l}$ in pond-I in 15 July, 2008. The average values of the dissolved oxygen contents observed in the ponds I, II and III were $5.325 \pm 0.22,5.20 \pm 0.27$ and $4.812 \pm 0.30 \mathrm{mg} / \mathrm{l}$, respectively (Table 3 ).

\section{pH (hydrogen-ion-concentration)}

The values of $\mathrm{pH}$ ranged from 6.30 to 8.00 during the study period (Table 2). The maximum value of $\mathrm{pH}$ 8.00 was noted in pond-I in 15 July, 2008. Whereas the minimum value of $\mathrm{pH} 6.30$ was noted in pond-III in 30 October, 2008. The values of $\mathrm{pH}$ recorded in the ponds-I, II and III were $7.10 \pm 0.16,7.063 \pm 0.19$ and $6.763 \pm 0.13$ (Table 3).

Table 2. Fortnightly variation of water temperature dissolved oxygen and $\mathrm{pH}$ during the period of experiment under different ponds

\begin{tabular}{|l|l|c|c|c|c|c|c|c|c|}
\hline Ponds & Parameters & $\begin{array}{c}15 \text { July, } \\
08\end{array}$ & $\begin{array}{c}30 \text { July, } \\
08\end{array}$ & $\begin{array}{c}15 \text { Aug., } \\
08\end{array}$ & $\begin{array}{c}30 \text { Aug., } \\
08\end{array}$ & $\begin{array}{c}15 \text { Sep., } \\
08\end{array}$ & $\begin{array}{c}30 \text { Sep. } \\
08\end{array}$ & $\begin{array}{c}15 \text { Oct. } \\
08\end{array}$ & $\begin{array}{c}30 \text { Oct. } \\
08\end{array}$ \\
\hline \multirow{3}{*}{ Pond-I } & Temperature $\left({ }^{\circ} \mathrm{C}\right)$ & 31.2 & 31.5 & 30.9 & 30.4 & 29.8 & 29.5 & 29.0 & 29.2 \\
\cline { 2 - 10 } & Dissolved oxygen $(\mathrm{mg} / \mathrm{l})$ & 5.9 & 5.3 & 5.5 & 5.6 & 5.3 & 5.2 & 5.0 & 4.9 \\
\cline { 2 - 10 } & $\mathrm{pH}$ & 8.0 & 7.7 & 7.5 & 7.3 & 7.0 & 6.6 & 6.4 & 6.5 \\
\hline \multirow{3}{*}{ Pond-II } & Temperature $\left({ }^{\circ} \mathrm{C}\right)$ & 30.5 & 30.8 & 31.1 & 30.7 & 29.5 & 29.2 & 29.0 & 28.8 \\
\cline { 2 - 9 } & Dissolved oxygen $(\mathrm{mg} / \mathrm{l})$ & 5.8 & 5.2 & 5.6 & 5.3 & 5.0 & 5.1 & 4.8 & 4.7 \\
\cline { 2 - 9 } & $\mathrm{pH}$ & 7.5 & 7.9 & 7.4 & 7.0 & 6.9 & 6.5 & 6.6 & 6.7 \\
\hline \multirow{3}{*}{ Pond-III } & Temperature $\left({ }^{\circ} \mathrm{C}\right)$ & 31.4 & 31.0 & 30.9 & 30.5 & 30.0 & 29.7 & 28.9 & 28.5 \\
\cline { 2 - 9 } & Dissolved oxygen $(\mathrm{mg} / \mathrm{l})$ & 5.45 & 5.0 & 4.8 & 4.85 & 4.65 & 4.30 & 4.40 & 4.55 \\
\cline { 2 - 10 } & $\mathrm{pH}$ & 7.2 & 7.0 & 6.9 & 6.7 & 6.4 & 6.7 & 6.9 & 6.3 \\
\hline
\end{tabular}


Table 3. Average values $( \pm$ SE) of water quality parameters in different pond throughout the whole experiment period

\begin{tabular}{|c|c|c|c|}
\hline Ponds & Temperature $\left({ }^{\circ} \mathrm{C}\right)$ & Dissolved oxygen $(\mathrm{mg} / \mathrm{l})$ & $\mathrm{pH}$ \\
\hline Pond-I & $30.188 \pm 0.84$ & $5.325 \pm 0.22$ & $7.100 \pm 0.16$ \\
\hline Pond-II & $30.00 \pm 0.72$ & $5.200 \pm 0.27$ & $7.063 \pm 0.19$ \\
\hline Pond-III & $30.111 \pm 0.85$ & $4.812 \pm 0.30$ & $6.763 \pm 0.13$ \\
\hline
\end{tabular}

\section{Survival of fish}

The survival rate $(\%)$ is presented in Table 5. The survival rate $(\%)$ of pangus were $98.66 \%, 85.06 \%$ and $80.00 \%$ in the pond-I, Pond-II and Pond-III, respectively. The survival rate (\%) of shing was $80 \%$ in pond-I. The highest survival rate $(\%)$ of pangus (98.66\%) was noted in pond-I where shing $(H$. fossilis) was stocked with pangus. The lowest survival rate $(\%)(80 \%)$ of pangus was observed in pond-III.

Table 4. Survival rate (\%) of Pangus (P. hypopthalmus) and Shing (H. fossilis)

\begin{tabular}{|l|c|c|c|c|c|}
\hline Ponds & Fish species & No. of fish stocked & No. of fish survival & Survival rate (\%) & $\begin{array}{l}\text { Stocking density per } \\
\text { decimal }\end{array}$ \\
\hline Pond-I & Pangus & 1500 & 1480 & 98.66 & 150 \\
\cline { 2 - 6 } & Shing & 100 & 80 & 80.00 & 10 \\
\hline Pond-II & Pangus & 3750 & 3190 & 85.06 & 250 \\
\hline Pond-III & Pangus & 4500 & 3600 & 80.00 & 300 \\
\hline
\end{tabular}

\section{Growth performance of the fishes}

\section{Fish growth}

The fortnightly growth performances (weight) of pangus ( $P$. hypophthalmus) are shown in Table 5. There was significant difference $(\mathrm{P}<0.05)$ in different ponds. The highest mean weight gain $(385.17 \pm 2.15 \mathrm{~g})$ of pangus was found in pond-I whereas the lowest mean weight gain $(319.30 \pm 2.90 \mathrm{~g})$ was found in pondIII. The mean weight gain of shing was found
$60.95 \pm 3.10 \mathrm{~g}$ in pond-I (Table 6). The growth performance such as mean weight $(\mathrm{g})$, specific growth rate (\% per day) and production of the fishes of different ponds are shown in Table 6. The specific growth rate (\% per day) was the highest $(2.53 \pm 0.05)$ for pangus in pond-I and the lowest $(2.046 \pm 0.05)$ for pangus in pond-II. Specific growth rate (\% per day) of shing (H. fossilis) was $0.968 \pm 0.06$.

Table 5. Growth of pangus in every fifteen days interval

\begin{tabular}{|c|c|c|c|c|c|c|c|c|c|}
\hline Ponds & $\begin{array}{c}\text { Initial } \\
\text { weight } \\
(\mathrm{g})\end{array}$ & $\mathbf{1 5}$ July, 08 & 30 July, 08 & $\begin{array}{c}15 \text { Aug. } \\
08\end{array}$ & 30 Aug. 08 & 15 Sept. 08 & 30 Sept. 08 & 15 Oct. 08 & 30 Oct. 08 \\
\hline Pond-I & 33.33 & 65.70 & 125.40 & 185.60 & 225.70 & 270.65 & 308.30 & 362.65 & 418.50 \\
\hline Pond-II & 30.50 & 55.55 & 102.35 & 153.80 & 184.50 & 221.50 & 262.00 & 305.40 & 355.65 \\
\hline Pond-III & 29.40 & 53.35 & 97.80 & 145.60 & 188.25 & 220.25 & 252.60 & 295.90 & 348.70 \\
\hline
\end{tabular}

Table 6. Mean weight gain (g) and specific growth rate (\% per day) and production of pangus (P. hypopthalmus) and shing (H. fossilis)

\begin{tabular}{|l|l|c|c|c|c|c|c|}
\hline Ponds & $\begin{array}{l}\text { Fish } \\
\text { species }\end{array}$ & $\begin{array}{c}\text { Mean initial } \\
\text { weight }(\mathrm{g})\end{array}$ & $\begin{array}{c}\text { Mean final } \\
\text { weight }(\mathrm{g})\end{array}$ & $\begin{array}{c}\text { Mean weight } \\
\text { gain }(\mathrm{g})\end{array}$ & $\begin{array}{c}\text { SGR }(\% \text { per } \\
\text { day })\end{array}$ & $\begin{array}{c}\text { Production } \\
\text { (kg/dec./4 } \\
\text { months })\end{array}$ & $\begin{array}{c}\text { Total } \\
\text { production } \\
\mathrm{kg} / \mathrm{ha} / \mathrm{yr}\end{array}$ \\
\hline Pond-I & Pangus & $33.33 \pm 2.50$ & $418.50 \pm 2.80$ & $385.17 \pm 2.15$ & $2.53 \pm 0.05$ & $57.00 \pm 0.19$ & $28158.00 \pm 0.10$ \\
\cline { 2 - 7 } & Shing & $4.5 \pm 2.90$ & $65.45 \pm 3.00$ & $60.95 \pm 3.10$ & $0.968 \pm 0.06$ & $0.487 \pm 1.35$ & $240.57 \pm 1.60$ \\
\hline Pond-II & Pangus & $30.50 \pm 2.90$ & $355.65 \pm 2.90$ & $325.15 \pm 2.70$ & $2.046 \pm 0.05$ & $69.148 \pm 0.30$ & $34159.112 \pm 0.5$ \\
\hline Pond-III & Pangus & $29.40 \pm 3.20$ & $348.70 \pm 3.10$ & $319.30 \pm 2.90$ & $2.06 \pm 0.06$ & $76.632 \pm 0.50$ & $37856.208 \pm 0.60$ \\
\hline
\end{tabular}

\section{Production of the fishes}

A comparative variation of production $(\mathrm{kg})$ of pangus in different ponds and the production of shing $(H$. fossilis) are shown in Table 6. There was a significant difference $(\mathrm{P}<0.05)$ in production of fishes among the experimental ponds. The production of pangus varied from $57.00 \pm 0.19$ to $76.632 \pm 0.50 \mathrm{~kg} / \mathrm{decimal} / 4$ months. Lower production $57.00 \pm 0.19 \mathrm{~kg} / \mathrm{decimal}$ of pangus was found in pond-I in which stocking density was minimum (150/decimal). Production of shing 
was $0.487 \pm 1.35 \mathrm{~kg} /$ decimal $/ 4$ month in pond-I along with pangus. Comparatively higher production (76.632 $\pm 0.50 \mathrm{~kg} /$ decimal $/ 4$ months) was found in pond-III in which stocking density was maximum (300/decimal) among all the ponds. Total production of pangus in different ponds ranged from $28158.00 \pm 0.10$ to $37856.20 \pm 0.60 \mathrm{~kg} / \mathrm{ha} / \mathrm{yr}$. Comparatively lower production $(28158.00 \pm 0.10)$ of pangus found in pond-I where stocking density was minimum (150 fingerlings/decimal) along with shing (10/decimal). In pond-I the production of shing was $240.57 \pm 1.60 \mathrm{~kg} / \mathrm{ha} /$ year.

\section{Food Conversion Ratio (FCR)}

In present study the food conversion ratio (FCR) was $1.53,1.81$ and 1.84 in ponds I, II and III respectively. Among the ponds lowest FCR (1.53) was found in pond-I whereas the highest FCR (1.84) was in pondIII (Table 7).

\section{Economic analysis}

A simple economic analysis was performed to estimate the net profit from monoculture of pangus and mixed culture of pangus and shing where shing was used to utilize the waste energy of the ponds. The cost of production was based on the Mymensingh wholesale market price of the year 2008 in consideration of the inputs used. The cost of artificial feed was BDT $21.00 / \mathrm{kg}$. Economic analysis was showed in table 7 .

Table 7. Economic analysis of fish ( $P$. hypophthalmus) and Shing (H. fossilis) at the end of the study period

\begin{tabular}{|l|c|c|c|}
\hline \multirow{2}{*}{ Investment cost (BDT) } & \multicolumn{3}{c|}{ Ponds } \\
\cline { 2 - 4 } & Pond-I & Pond-II & Pond-III \\
\hline Pond preparation & 210 & 300 & 150 \\
\hline Lime & 120 & 150 & 12350 \\
\hline Fingerling cost & 5700 & 10700 & 44465 \\
\hline Feed cost & 18280 & 39400 & 5150 \\
\hline Operational cost & 2190 & 4550 & 62415 \\
\hline Total production cost & 26500 & 55100 & 68968 \\
\hline Gross income from fish sale & 37573 & 62233 & 54.29 \\
\hline Cost/kg fish & 46.09 & 53.12 & 5.70 \\
\hline Profit/kg & 19.26 & 6.88 & 2117.38 \\
\hline Total amount of feed (kg) & 870.48 & 1876.19 & 1149.38 \\
\hline Total amount of fish (kg) & 570.00 & 1037.22 & 1.84 \\
\hline Food conversion ratio (FCR) & 1.53 & 1.81 & 1027767.00 \\
\hline Gross cost/ha (BDT) & 654550.00 & 907313.33 & 1135673.06 \\
\hline Gross return/ha (BDT) & 928053.10 & 1024770.06 & 107906.06 \\
\hline Net return/ha (BDT) & 273503.10 & 117456.73 & \\
\hline Sal prict Pond Pang & & \\
\hline
\end{tabular}

Sale price: Pond-I $\rightarrow$ Pangus $=$ BDT 62.5/kg, Pond-II $\rightarrow$ Pangus $=$ BDT 60.00/kg, Shing = BDT 400/kg

Pond-III $\rightarrow$ Pangus $=$ BDT $60.00 / \mathrm{kg}$, Feed cost: BDT $21.00 / \mathrm{kg}$

\section{Water quality parameters \\ Water temperature $\left({ }^{\circ} \mathrm{C}\right)$}

During the experiment period, the water temperature ranged from $28.5^{\circ} \mathrm{C}$ to $31.5^{\circ} \mathrm{C}$. The average water temperature recorded in ponds I, II and III were $30.188^{\circ} \mathrm{C}, \quad 30.00^{\circ} \mathrm{C}$ and $30.11^{\circ} \mathrm{C}$, respectively. Hossain (2009) recorded the range of water temperature from 27.3 to $32.3^{\circ} \mathrm{C}$. Hossain (2000) recorded the range of water temperature from 22 to $33^{\circ} \mathrm{C}$. Water temperature recorded in present study was on the suitable range for fish culture.

\section{Dissolved oxygen (mg/l)}

In the present study, the average dissolved oxygen contents were $5.325,5.200$ and $4.812 \mathrm{mg} / \mathrm{l}$ in ponds I, II and III respectively. The average temperature varied from 4.812 to $5.325 \mathrm{mg} / \mathrm{l}$. The fluctuation in dissolved oxygen value might be due to alteration in the rate of photosynthesis in the plants and also due to the rate of DO consumption by the fish species through respiration and decomposition of the leftover feed and faeces. Highest average dissolved oxygen content was found in pond-I where shing was stocked with pangus. Bacterial decomposition of waste feed and faces need a considerable amount of oxygen that reduces the dissolved oxygen content in ponds. Shing (H. fossilis) utilize the waste feed in pond-I and reduces bacterial decomposition that enhance dissolved oxygen content of the Pond-I. Hossain (2009) recorded dissolved oxygen from 5.1-8.7 mg/l. Roy (2001) recorded dissolved oxygen from 5.0-7.5 $\mathrm{mg} / \mathrm{l}$ in nine experimental ponds of the Faculty of Fisheries, BAU Campus Mymensingh. DoF (1998) reported that the suitable range of dissolved oxygen in 
waterbody for fish culture would be 5-8 ppm. For better growth and production suitable level of dissolved oxygen is essential. The result of this study was nearly similar to the findings of the above researcher.

\section{pH (Hydrogen-ion-Concentration)}

The $\mathrm{pH}$ values of the present study in different ponds varied from 6.763 to 7.10 . The average values of recorded $\mathrm{pH}$ in ponds I, II and III were 7.100, 7.062 and 6.763. During the study period the maximum value of $\mathrm{pH}$ was recorded in pond-I in 15 July, 2008. Whereas the minimum value of $\mathrm{pH}$ was recorded in pond-III in 30 October 2008. Hossain (2009) observed $\mathrm{pH}$ 7.1-7.2 in climbing perch culture. Kohinoor (2000) observed pH 6.9 to 8.6 in ponds of SIS polyculture. The $\mathrm{pH}$ values are considered as an important factor in fish culture. The $\mathrm{pH}$ value is slightly alkaline which indicate good productive condition of the ponds.

\section{Survival of fishes}

The survival rate of pangus of the present research work was $98.66 \%, 85.06 \%$ and $80.00 \%$ in the ponds I, II and III respectively. The highest survival rate of pangus was $98.66 \%$ in pond-I where stocking density was 150 pangus/decimal and 10 shing/decimal. The lowest survival rate of pangus was $80.00 \%$ in pondIII where stocking density was 300 pangus/decimal. Where as intermediate survival rate of $85.06 \%$ was observed at density of 250/decimal. The food conversion ratios (FCR) were 1.53, 1.81 and 1.84 in the pond I, II and III respectively. Shing utilize the waste feed in pond-I and makes the pond environmental suitable for fish. That is why survival rate of pangus in pond-I is highest. Ali (1998) found that survival rate of $P$. sutchi under three stocking densities of 120, 100 and 80 fish/decimal were $90 \%$, $90 \%$ and $92.08 \%$ respectively, while the food conversion rations was $1.73,1.77$ and 1.68 respectively. These findings more or less agreed with the findings of the present study. In the present experiment it was observed that in pond-I less feed is required to produce pangus in addition with that less food provides a supplementary production of high pride shing.

\section{Growth performance of the fishes Weight gain}

The average weight gain of pangus was highest $(385.17 \pm 2.15 \mathrm{~g})$ in the pond-I where stocking density was minimum (150/decimal) and where shing $(H$. fossilis) was stocked with pangus at the rate of $10 /$ decimal. The lowest weight gain $(319.30 \pm 2.90 \mathrm{~g})$ of pangus found in the pond-III, where stocking density was maximum (300/decimal). In the pond-II, moderate weight gain $(325.15 \pm 2.70 \mathrm{~g})$ was found where stocking density was $250 /$ decimal. In lower density, highest weight gain was found due to better utilization of feed and waste energy used by shing. Hossain (2001) reported that within 4 to 5 months it is possible to produce more than $500 \mathrm{~g}$ of individual catfish having market demand.

\section{Specific growth rate (\% per day)}

The specific growth rate (\% per day) of pangus was $2.53,2.05$ and 2.06 in the pond I, II and III respectively. The highest specific growth rate (\% per day) is found in pond-I. Hung et al. (1998) conducted an experiment with $P$. hypophthalmus reared in outdoors concrete tanks and concluded that a frequency of feeding twice daily had a good effect on and SGR of 3.34 was observed .

\section{Production of the fishes $(\mathrm{kg} / \mathrm{ha} / \mathrm{yr})$}

In the present research work the total production were $28158.00,34159.112$ and $37856.208 \mathrm{~kg} / \mathrm{ha}$. The highest production of pangus was $37856.208 \mathrm{~kg} / \mathrm{ha} / \mathrm{yr}$ in pond-III whereas the lowest production was $28158.00 \mathrm{~kg} / \mathrm{ha} / \mathrm{yr}$ in pond-I. The production of shing was $240.57 \mathrm{~kg} / \mathrm{ha} / \mathrm{yr}$ in pond-I along with pangus. In pond-I the stocking density was $150 /$ decimal whereas $300 /$ decimal pangus was stocked in pond-III. The highest production was found in the lowest stocking density, might be due proper utilization of feed and healthy environmental of the pond. Akter (2001) conducted a survey in Trishal upazila under Mymensingh district and found that average production of pangus was $20112.35 \mathrm{~kg} / \mathrm{ha} / \mathrm{yr}$. Kausari (2001) found that average production of pangasius was $21340 \mathrm{~kg} / \mathrm{ha}$. Hossain (2006) in the study area of Mymensingh the average production was 14,943 $\mathrm{kg} / \mathrm{ha} / \mathrm{yr}$. So, the level of fish production in the present study was nearly similar to the result of the quoted researcher.

\section{Economic analysis}

During economic analysis of the present study, it was found that the gross cost/ha, gross return/ha and net return/ha of the pond-I were BDT 654550, 928053.1 and 273503.1, respectively. Incase of the pond-II and pond-III gross cost/ha, gross return/ha, net return/ha were BDT 907313.33, 1024770.06, 117456.73 and BDT 1027767.0, 1135673.06, 107906.06 respectively. The highest net return per ha (BDT 273503.1) and lowest gross cost per ha were found in pond-I whereas the lowest net return per ha and highest gross cost per ha were found in pond-III. In pond-I, stocking density of pangus was minimum and shing was stocked with pangus as guest without providing extra feed which is profitable than other ponds in which stocking density of pangus was higher. In pond-II, moderate production was found. This might be due to the utilization of waste energy by shing in pond-I, that also might helped to improve 
the physio-chemical properties of water by reducing decomposition. Akter (2001) reported, per ha gross cost of pangusis production was BDT 286932.84 and gross return and net return were BDT 546473.07 and BDT 259502.91 respectively which indicated that the pangasius fish production was a profitable enterprise. Feed was supplied at the same rate in all the ponds but the result indicate that the pond stock with pangus and shing the individual growth of pangus was higher at the same time and additional amount of shing was produced which indicate the use of left-over feed utilization by the production of shing. In the present study profit was highest in lowest density where shing was added to utilize waste energy. The technology of culturing pangus (37050 fry/ha) with shing (2470 fry/ha) can be suggested after trial for marginal farmer engaged in pangus culture for effective utilization of their limited resources.

\section{Conclusion}

From the experiment it was found that the total production was increased with increasing stocking density. But the individual fish growth was decreased with increasing stocking density. That is why the market price of per $\mathrm{kg}$ fish was lower in the higher stocking density than lower stocking density. FCR was lower in the ponds where stocking density was minimum and shing was stocked with pangus. This might be due to proper utilization of artificial feed and the utilization of waste energy by shing that also helped to improve the physico-chemical properties of water. Therefore, the fish farmers are encouraged to culture pangus with shing in low stocking density for the effective utilization of the limited resources of the marginal aquaculturists.

\section{References}

ADCP, 1983. Fish feeds and feeding in developing countries. Aquaculture Development and Coordination Programme.ADCP/PEP/83/18. UNDP/FAO, $97 \mathrm{pp}$.

Akand, A. M.; Hsaan, M. R. and Habib. M. A. B. 1991. Utilization of carbohydrate and lipid as dietary energy sources by stinging catfish (Heteropneustes fossilis). In S.S. De Silva (ed.). Fish nutrition research in Asia. Proceedings of the Fourth Asian Fish Nutrition Workshop. Asian Fisheries Society, Manila, Phillipines. pp. 93-100.

Akter, N. 2001. An economic analysis of pond pangas fish production in a selected area of Trishal upazilla in Mymensingh district. MS Thesis. Department of Agriculture Economics, BAU, Mymensingh. 44 pp.
Ali, M. A. 1998. Effects of stocking density on growth and production of Thai pangas (Pangasius sutchi Fowler). MS Thesis. Department of Fisheries Biology and Genetics, BAU, Mymensingh. 63 pp.

Bardach, J. E.; Ryther, J. H. and Mclarney, W. O. 1972. The farming and Husbandry of freshwater and marine organisms. Wiley inter Science, Administration of Jhon Wiley and Sons. Inc. New York. 868 pp.

Das, B. K. 1972. The bionomics of certain airbreating fishes of India together with an account of the development of their airbreathing organs. Phil. Trans., 216: 183-219.

Department of Fisheries, 2005. Smaranica: Mastshwa Sapta 2005. Department of Fisheries, Ministry of Fisheries and Livestock, Government of the People Republic of Bangladesh Ramna, Dhaka. 109 pp.

DoF, (Department of Fisheries). 1998. Matshya Saptah Shankalan. 1998. Directorate of Fisheries, Bangladesh. 101 pp.

Hossain M. M. 2009. Effects of partial Replacement of fishmeal by fermeted soyabean meal and squid by product blend in the diet of climbing perch (Anabas testudines). MS Thesis. BAU. Department of Aquaculture. BAU, Mymensingh. 19 pp.

Hossain, A. 2006. An economic analysis of pangas farming in rural Bangladesh. MS Thesis. Department of Fisheries. Management, BAU, Mymensingh. 87 pp.

Hossain, M. E. 2001. Effect of stocking density on the growth, survival and production of Thai pangas (Pangasius hypophthalmus). MS Thesis. Department of Aquaculture, BAU, Mymensingh. 49 pp.

Hossain, M. Y. 2000. Effect of iso-phosphorus organic and inorganic fertilizer on water quality parameters and biological production. M.S. Thesis, Department of Fisheries Management, Faculty of Fisheries, Bangladesh Agricultural University, Mymensingh, 74 pp.

Hung, L.; Tuan, N. and Lazard, J. 1998. Effects of frequency and period of growth and feed utilization in two Asian catfishes, Pangasisu bocouriti (Sauvage, 1980 and Pangasius hypophthalmus (Sauvage, 1987). In: the biological diversity and aquaculture of Clariid and pangasiid catfishes in South-east Asia. Proceedings of the mid term workshop 
of the "Catfish Asia Project" Cantho, Vietnam. Mare Legendra and Antoine Pariselle ed., pp. 157-166.

Kausari, M. M. T. 2001. An economic study of pangas fish culture in selected area of Mymensingh and Jamalpur district. MS Thesis. Department of Agricultural Economics, BAU, Mymensingh. 89 pp.

Kohinoor, A. H. M. 2000. Development of culture technology of three small indigenous fish mola (Amblypharyngodon mola), Punti (Puntius sophore) and Chela (Chela cachius) with notes on some aspects of their biology. Ph.D Thesis. Department of Fisheries Management, Bangladesh Agricultural University, Mymensingh, pp. 91-102.
Roy, K. 2001. Effect of stocking density on the growth of carps in ponds. M.S. Thesis, Dept. of Aquaculture, Bangladesh Agricultural University, Mymensingh. 72 pp.

Talwar, P. K. and Jhingran, A. G.1992. Inland fishes of India and adjacent countries, Vol. 2. Oxford and IBH Publishing Co. Pvt. Ltd. New Delhi, India. 1158 p. Vietnam, 5-7 Dec., 2008.

Wahab, M. A.; Faruk, M. A. R.; Haque, M. M. and Hossain, M. S. 2008. Paper presented Pangasius (Pangasianodon hypophthalmus) farming in Bangladesh: current status and future challenges in the catfish symposium in Can Tho University, Can. Tho. Vietnam, 5-7, Dec., 2008. 